\title{
Jakaś niedzisiejsza... Śmierć i starość w obiektywie filmowej kamery
}

\section{Somehow out-of-date... Death and old age through the lens of a video camera}

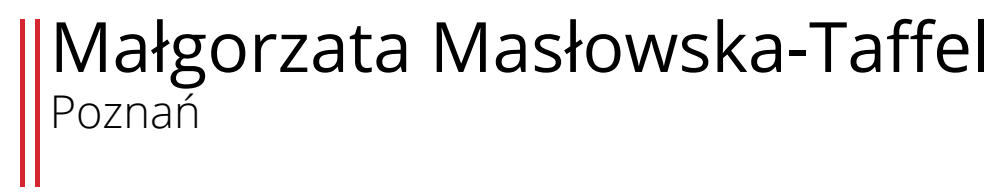

„...ppokazywać to, co zabronione, odsłaniać to, co kryte” (Nowakowski 2009, 163)

\begin{abstract}
The article is devoted to the use of a feature film with reference to the practice of Polish language teaching at the middle school level. Starting with a detailed reconstruction of the attitudes of the characters, going through the analysis of the film means of expression, the author embeds the movie Pora umierać (Time to Die) by Dorota Kędzierzawska (2007) in the axiological context, in the circle of harsh reflections related to the death and old age. The analysis is complemented by the presentation of some specific methodological solutions and visualization of the issues raised in the film in the form of tables and graphs.
\end{abstract}

Key words: thanatology, taboo, middle school didactics, visualization, scenography, film education.

Streszczenie: Artykuł poświęcony jest odniesieniom filmu fabularnego do praktyki polonistycznej na poziomie gimnazjum. Wychodząc od szczegółowej rekonstrukcji postaw bohaterek, analizując warsztat filmowych środków wyrazu, autorka osadza film Pora umierać Doroty Kędzierzawskiej (2007) w kontekście aksjologicznym, w kręgu trudnych refleksji związanych ze śmiercią i starością. Analizę dopełnia wskazanie konkretnych rozwiązań metodycznych i wizualizacja problematyki filmu w formie tabel i grafów.

Słowa kluczowe: tanatologia, dydaktyka gimnazjalna, wizualizacja, scenografia, edukacja filmowa.

Gdyby zapytać nastolatka, ucznia gimnazjum, szkoły średniej o jego gusta filmowe, odpowiedź zapewne brzmiałaby: konieczna szybka akcja, sensacyjne wydarzenia i wartkie dialogi. Czy więc jest sens proponować młodzieży obejrzenie filmu, który zamiast wymienionych atutów przedstawia raczej nastroje, spojrzenia, gesty; zamiast kryminalnej 
intrygi, szalonego pościgu, romantycznej fabuły, nostalgiczną, poetycką opowieść o starości, przemijaniu i samotności? Pora umierać Doroty Kędzierzawskiej (2007) to film, który był wielokrotnie nagradzany przez krytyków i filmoznawców, widzów dojrzałych. Zastanawiające jest, czy zyska on również uznanie młodego widza? Trochę się obawiam, że gimnazjaliści zareagują na niego tak jak pewna dziewczyna, zwracając się do swego chłopaka w kinie: „Starość jest jednak jakaś niedzisiejsza, idziemy stąd, następnym razem wymyśl coś lepszego. Żeby jakaś fabuła była chociaż" (zasłyszane). Ponieważ oglądanie filmów jest ciągle najpopularniejszym sposobem spędzania czasu wśród młodych ludzi, szkoła winna budować krytyczny odbiór filmu, rozwijać wśród młodzieży refleksję wartościującą (Bobiński 2010). Sztuka filmowa kierowana dla dzieci i młodzieży w prezentacji świata nawiązuje do doświadczeń wypracowanych przez kino dla starszych widzów (Nowakowski 2009). Proponowany młodzieży film, choć nie mieści się w spisie obrazów dla młodego widza, ma szansę być właściwie przez niego odczytany, oswoić go ze społecznym tabu, poruszyć wątek komunikacji międzypokoleniowej. Celem cyklu lekcji ${ }^{1}$, który opisuje $\mathrm{w}$ artykule, jest przekonanie ucznia o artystycznych walorach filmu Kędzierzawskiej, a jednocześnie refleksja nad tym, jak motyw śmierci i starości prezentuje się w niebanalnym, dalekim od disneyowskiego kiczu, obrazie. Analizowany film nie jest bowiem adaptacją literacką, ale zawiera ciekawą grę prowadzoną $\mathrm{z}$ dawną literaturą, z ujęciem śmierci w sonetach Williama Szekspira, co wymusza ujęcia komparatystyczne. Ciekawe okaże się również zderzenie z szablonami obyczajowymi, przekonaniami dotyczącymi „starości” i „młodości”, które często funkcjonują jak szkodliwy wirus myślowy, co próbuje przełamać się współcześnie w ramach prężnie rozwijającej się geriatrii, a co twórcy filmu pokazują w artystycznej formie.

\section{Motyw śmierci}

Według Jacka Kolbuszewskiego, literaturoznawcy i tanatologa, śmierć przestała pasować do współczesnego świata. Nie wpisuje się w obowiązujący model kultury, nie koresponduje z sukcesem, karierą, zabawą, kultem młodości. Jest odległa, wyparta ze świadomości człowieka. Liczby pokazują, jak wielu ludzi umiera w szpitalach, anonimowo, w domach opieki, bez asysty rodziny, pożegnania. W Niemczech, a także w Czechach, rodzina czuje się zwolniona z jakichkolwiek obowiązków wobec zmarłego, w Szwajcarii nie uczestniczy nawet w pochówku. Odsuwa się wnuki od śmierci dziadków.

1 Cykl lekcji jest rozpisany wokół dwóch motywów: śmierci i starości. Pierwszy z nich (2-3 godziny lekcyjne) wymaga od nauczyciela zebrania spostrzeżeń uczniów na temat traktowania śmierci we współczesnym świecie, przeprowadzenia analizy korespondujących ze sobą sekwencji filmowych: „próby odejścia” i „śmierci właściwej” bohaterki, oraz sformułowania wniosków wynikających z tego zestawienia. W dalszej części cyklu (2-3 godziny lekcyjne) przedmiotem dyskusji staje się pojęcie starości, uczniowie zaczynają od analizy pojedynku: babcia wnusia, by następnie przejść do odtworzenia hierarchii wartości obu bohaterek i oceny ich postaw. Obie części cyklu zamykają zadania redakcyjne: wpis na czat bądź opinia na temat postaci. 
To powoduje irracjonalne poczucie nieśmiertelności człowieka. A w momencie zgonu kogoś bliskiego sytuacja staje się traumą, do której nie jesteśmy przygotowani. W codziennym życiu współczesnego człowieka miejsca na śmierć już prawie nie ma (Kolbuszewski 2007). Stąd tak ważne staje się odnalezienie tego motywu we współczesnym obrazie filmowym, poszerzonym o renesansowy kontekst, co pozwoli uczniowi wykorzystać swoją wiedzę o literackich i filmowych środkach przekazu i skonfrontować się $\mathrm{z}$ tym trudnym tematem. Śmierć ciągle funkcjonuje $\mathrm{w}$ świecie młodych jako rodzaj tabu, Nowakowski odnajduje jednak przykłady wartościowych filmów dla młodzieży poruszających ten temat; są to m.in. Leon i Olvido Xaviera Bermudeza (2004), Niebieskie światło Yukio Ninagawy (2003), Przekleństwa niewinności Sofii Coppoli (1999) czy w końcu Czwarte piętro Antonia Mercero (2003) - film często wykorzystywany w praktyce nauczyciela polonisty.

Czy śmierć przestała pasować do współczesnego świata? Takie pytanie powinno otworzyć cykl zadań opartych na porównaniu renesansowej filozofii „odejścia” i współczesnego traktowania śmierci. Inspirująca może się okazać rozmowa z uczniami na temat postrzegania śmierci we współczesnym świecie na podstawie czatu internetowego z księdzem Piotrem Krakowiakiem - krajowym duszpasterzem hospicjów. Zaprezentowane fragmenty (Krakowiak 2010) zawierają ważne tezy związane z omawianym problemem:

Myszka15bi: Czemu ludzie boją się śmierci skoro to naturalne? Ja się nie boję śmierci tylko umierania.

Krakowiak: Ludzie boją się i umierania, i śmierci. Jako społeczeństwo wolimy o tym nie mówić i myśleć, że jesteśmy nieśmiertelni. To wielka ściema współczesnej kultury.

Rexon: Myślę, że to nie ściema współczesnej kultury, że człowiek stara się myśleć, że nie umrze nigdy. To forma obrony przed śmiercią, wpisana niejako w jego psyche. Pozbawianie go tego może być niebezpieczne.

Krakowiak: Drogi Rexonie, statystyki są nieubłagane - 100 procent ludzi umiera. Warto o tym pamiętać. Może zamiast zawiłego filozofowania warto powrócić do dobrej tradycji ars moriendi, czyli takiego życia, żeby nie obawiać się śmierci. Niunia1705: Czy nosząc żałobę, trzeba zakładać same czarne ubrania, czy można nosić ją w sercu?

Krakowiak: W naszej tradycji czarny strój to żałoba. Ale już w Japonii nosi się białe ubrania. Najważniejsze jest to, co w sercu i to, co najbardziej się liczy, to szczera modlitwa i życzliwe mówienie o zmarłej osobie.

malarz: Czego człowiek żałuje, a z czego jest zadowolony na łożu śmierci? Jakie przesłania zostawiają umierający?

Krakowiak: Każdy z nas jest inny. I każde umieranie jest inne. Słowa piosenki „Jakie życie taka śmierć" są bardzo prawdziwe. Zdarza się jednak, że ludzie nawracają się i zmieniają w obliczu śmierci. Jest to z pewnością łaska. Ktoś musi modlić się za nich i dobrze im życzyć. Dlatego oprócz obecności przy umierającym ważna jest modlitwa.

Villia: Dlaczego tak trudno przygotować się do śmierci, choć mamy na to całe życie??? 
Krakowiak: Wydaje się, że nie przygotowujemy się do tego egzaminu, bo przez 40 lat życia udajemy, że nie ma tego tematu. A następne 40 myślimy, że to dotyczy tylko innych. Nasza kampania społeczna HOSPICJUM TO TEŻ ŻYCIE próbuje to zmienić. Zapraszamy do włączenia się w naszą kampanię!

Zakładam, że wnioski młodzieży będą krążyć wokół tez interpretacyjnych, które można wykorzystać jako alternatywne, samodzielnie wymyślone tematy lekcji, co wzmocni podmiotowość uczniów; będą to np. „Nikt nie mówi o śmierci”, „Śmierć jest anonimowa”, „Rodzina nie uczestniczy w odejściu seniorów rodu”. Do właściwej realizacji zajęć konieczne jest przypomnienie dwóch fragmentów filmu Kędzierzawskiej (przypomnienie, bowiem zakładamy, że całość filmu uczniowie obejrzą już wcześniej): a) Aniela szykuje się do śmierci (sekwencja 7 min.), b) Aniela umiera (sekwencja końcowa 7 min.). Ponieważ bohaterka wypowiada w formie monologu sonet Szekspira, należy udostępnić uczniom tekst utworu. Staruszka oczekuje na śmierć, leżąc na łóżku i trzymając w dłoniach różaniec, zamiast modlitwy widz słyszy „pochodzący z jej głowy” fragment Sonetu 73 Szekspira w tłumaczeniu Jerzego Sito (słowa wypowiedziane zaznaczam pogrubieniem):

Oto już jesień i pora umierać;

pożółkłe liście wiatr strąca i miecie,

drżące gałęzie do naga obdziera -

chór, gdzie sto ptaków modliło się w lecie.

Ja jestem zmierzchem dnia, który się skłania

ku zachodowi i w ciemności brodzi;

noc, siostra śmierci, oczy mi przysłania

i wkrótce $z$ całym światem mnie pogodzi.

Żar we mnie drzemie, lecz żar jaki bywa

gdy młodość już się oblecze popiołem;

jako na łożu śmierci dogorywam

strawiony przez to, co sam od niej wziąłem.

A skoro kochasz, choć prawdę dostrzegniesz,

kochasz tym mocniej, im rychlej odbiegniesz (Shakespeare, 1964).

Na potrzeby filmu zostały wykorzystane dwie części utworu: obraz jesieni - zamierania świata, co symbolizuje schyłkową fazę życia człowieka, oraz końcowa część refleksyjna, zawierająca wskazówkę życiową. Ostatnie wersy sonetu szekspirolodzy interpretują jako powracającą w sonetach aluzję do tajemniczej osoby i związanego z nią uczucia. Jednak w filmie zyskują one inny sens, po wypowiedzeniu tych słów Aniela zrywa się oburzona na siebie samą, uświadamia sobie największą wartość ludzkiego losu - umiłowanie życia we wszystkich jego przejawach, stąd możliwa jest interpretacja porównawcza tych słów z odwołaniem do tekstu i filmu. ${ }^{2}$

Kluczowe zadanie zaplanowanej lekcji to obserwacja bohaterki w dwóch fragmentach filmu, analiza sceny „szykowania się na ostatnią droge” oraz

${ }^{2}$ Podobną interpretację sugeruje tłumaczenie S. Barańczaka: „Ujrzysz - lecz zaczniesz odtąd, zwykłym serca prawem,/Kochać goręcej to, co stracić masz niebawem." 
kontrastowej do niej, właściwej sceny „odejścia”. Film podpisywany czy komentowany jest jako dzieło Kędzierzawskiej (scenarzystki, reżyserki), ale również Arthura Reinharta (autora zdjęć), dlatego należy zwrócić uczniom uwagę na znaczenie strony plastycznej filmu. Wydaje się, że przedwojenna drewniana willa i jej wnętrze spełniły podobne warunki jak podwarszawski dom, który wybrał Allan Starski do realizacji Panien z Wilka Andrzeja Wajdy (1979). Wprowadziły do filmu „niepowtarzalny klimat emocjonalny" (Hendrykowska 1999, 314). Najważniejsze środki wykorzystane przez twórców to także: operowanie światłem, czarno-białe zdjęcia wymagające od widza skupienia oraz oszczędność filmowej narracji. Powstał film w swej formie i plastyce prawdziwie poetycki. Uczniowie powinni zintegrować swoje spostrzeżenia plastyczno-filmowe z interpretacją sceny, budując notatkę $\mathrm{w}$ takim oto zestawieniu:

\begin{tabular}{|c|c|c|}
\hline $\begin{array}{l}\text { Co robi bohaterka } \\
\text { filmu? }\end{array}$ & $\begin{array}{l}\text { Jak scena jest ukształto- } \\
\text { wana? } \\
\text { (środki filmowe: świa- } \\
\text { tło, montaż, kadrowa- } \\
\text { nie, scenografia) }\end{array}$ & Co bohaterka mówi? \\
\hline $\begin{array}{l}\text { Wyciąga z szafy czarną } \\
\text { suknię. } \\
\text { Zasłania okna. } \\
\text { Wkłada czarne buty. } \\
\text { Maluje szminką usta, } \\
\text { później ściera. } \\
\text { Zasłania lustro. } \\
\text { Zatrzymuje zegar. } \\
\text { Poprawia poduszkę. } \\
\text { Zapala świecę. } \\
\text { Ustawia święty obrazek. } \\
\text { Oplata złożone dłonie } \\
\text { różańcem. } \\
\text { Przyjmuje pozycję } \\
\text { leżąca. } \\
\text { Zrywa się nagle. }\end{array}$ & $\begin{array}{l}\text { Czarno-biały negatyw; } \\
\text { przyciemniony pokój, } \\
\text { półmrok. } \\
\text { Światło pada przez } \\
\text { szczeliny zasłon; cienie, } \\
\text { półcienie. } \\
\text { Liczne zbliżenia i detale } \\
\text { podkreślające etapy } \\
\text { przygotowania: ręka } \\
\text { zatrzymująca wahadło } \\
\text { zegara, stopa wciskana } \\
\text { w but, płomień świecy, } \\
\text { różaniec na palcach. }\end{array}$ & $\begin{array}{l}\text { „Oto już jesień i pora } \\
\text { umierać; pożółkłe liście } \\
\text { wiatr strąca i miecie, } \\
\text { drżące gałęzie do naga } \\
\text { obdziera - chór, gdzie } \\
\text { sto ptaków modliło } \\
\text { się w lecie. Ja jestem } \\
\text { zmierzchem dnia, który } \\
\text { się skłania ku zachodowi } \\
\text { i w ciemności brodzi; } \\
\text { noc siostra śmierci, oczy } \\
\text { mi przysłania i wkrótce } \\
\text { z całym światem mnie } \\
\text { pogodzi. Żar we mnie } \\
\text { drzemie, lecz żar jaki } \\
\text { bywa gdy młodość już się } \\
\text { oblecze popiołem; jako } \\
\text { na łożu śmierci dogory- } \\
\text { wam, strawiony przez to, } \\
\text { co sam od niej wziąłem. } \\
\text { A skoro kochasz, choć } \\
\text { prawdę dostrzegniesz, } \\
\text { kochasz tym mocniej, } \\
\text { im rychlej odbiegniesz". } \\
\text { (słyszane zza kadru) } \\
\text { Czyś ty zwariowała? } \\
\text { Umierać! (sama do siebie) }\end{array}$ \\
\hline
\end{tabular}




\begin{tabular}{|c|c|c|}
\hline $\begin{array}{l}\text { Wnioski: } \\
\text { Scena to rytuał śmierci, } \\
\text { przygotowania organi- } \\
\text { zacyjne i symboliczne. } \\
\text { Aniela sama sobie orga- } \\
\text { nizuje śmierć (paradoks } \\
\text { - samotna, opuszczona, } \\
\text { nie chce nikomu zawa- } \\
\text { dzać, ale nawet zgon } \\
\text { musi sobie sama zorga- } \\
\text { nizować). Początkowo } \\
\text { jest wola śmierci, ale } \\
\text { nie ma gotowości ciała } \\
\text { (paradoks - zazwyczaj } \\
\text { człowiek chce żyć, } \\
\text { ma tyle do zrobienia, } \\
\text { ale organizm odma- } \\
\text { wia posłuszeństwa). } \\
\text { Odczuwa wewnętrzny } \\
\text { bunt. }\end{array}$ & $\begin{array}{l}\text { Wnioski: } \\
\text { Scenę charakteryzuje } \\
\text { oszczędność środków, } \\
\text { surowość formy; auto- } \\
\text { rzy budują intymność } \\
\text { sceny. }\end{array}$ & $\begin{array}{l}\text { Wnioski: } \\
\text { Pogodzenie ze zbliżającą } \\
\text { się śmiercią jest natu- } \\
\text { ralną konsekwencją ludz- } \\
\text { kiej egzystencji. Można } \\
\text { zauważyć: harmonię } \\
\text { „odejścia”; wyrażenie } \\
\text { momentu - aktu śmierci; } \\
\text { diagnozę dotyczącą ludz- } \\
\text { kiego losu - to, co wzią- } \\
\text { łem, teraz oddaję. } \\
\text { Bohaterka wyraża } \\
\text { wewnętrzny bunt (coś jest } \\
\text { jeszcze do zrobienia!). }\end{array}$ \\
\hline
\end{tabular}

Po ustaleniu i zapisaniu wniosków do każdej z części tabeli można zamknąć tę część zajęć werbalizacją następujących spostrzeżeń:

- Zauważalny dysonans: harmonię odejścia, pogodzenie się z losem opisane w sonecie łączą się z zaskakującą puentą sceny filmowej powrotem do życia.

- Samotność śmierci staruszki, brak rodziny. Przyczyną decyzji o śmierci jest motywacja, by nie zawadzać bliskim, usunąć się, „pora umierać”.

- Sekwencja filmowa bogata w symbolikę śmierci. Obok kultury chrześcijańskiej (zapalenie świecy, różaniec, święty obrazek - pojednanie z Bogiem, światłość wiekuista), można wyliczyć gesty pochodzące $\mathrm{z}$ tradycji ludowej. Przykrywanie lustra to symboliczny gest zapobiegający utrwaleniu się na tafli lustrzanej odbicia zmarłego oraz nagłej śmierci innej osoby, która zajrzałaby do zwierciadła. Lustro to rodzaj granicy między światem żywych a niebezpiecznym światem zmarłych. Zatrzymywanie wskazówek zegara to z kolei znak ciszy i spokoju, jaki należy się zmarłemu (Kowalski 2007, 288-289).

- Korespondencja montażu, kadrowania z tematem sceny, malarskie światło.

- Film Kędzierzawskiej i Reinharta ma z pewnością „styl i barwę, pewien ton osobisty" (Hendrykowska 1999, 316).

Podczas odtwarzania i analizy drugiego fragmentu filmu można dostrzec inne podejście bohaterki Anieli do własnej śmierci. Spostrzeżenia na ten temat, spisane w poniższej tabeli, mogą być przedmiotem swobodnej rozmowy, dyskusji problemowej bądź pracy w grupie. 


\begin{tabular}{|c|c|c|}
\hline Co robi bohaterka? & $\begin{array}{c}\text { Jak to jest pokazane? } \\
\text { (środki filmowe: światło, } \\
\text { montaż, kadrowanie, } \\
\text { scenografia ) }\end{array}$ & $\begin{array}{l}\text { Otoczenie, tło dźwię- } \\
\text { kowe }\end{array}$ \\
\hline $\begin{array}{l}\text { Wchodzi na piętro domu. } \\
\text { Siedzi na werandzie } \\
\text { w fotelu. } \\
\text { Towarzyszy jej pies. } \\
\text { Nieruchomieje, głowa } \\
\text { oparta na ramieniu. } \\
\text { Śmierć przypomina } \\
\text { spokojny sen w odbiciu } \\
\text { psich oczu. } \\
\text { Słowa bohaterki zza } \\
\text { kadru: „Dzięki Bogu nie } \\
\text { będę musiała pić herbaty } \\
\text { z kubka”. }\end{array}$ & $\begin{array}{l}\text { Synchroniczne plany } \\
\text { (widz obserwuje naprze- } \\
\text { miennie przeprowadzkę } \\
\text { dzieci i zasiedlenie na } \\
\text { parterze domu, i Anielę } \\
\text { na tarasie piętra). } \\
\text { Wolne wejście dziew- } \\
\text { czynki po schodach } \\
\text { z kubkiem herbaty dla } \\
\text { staruszki (zbliżenie na } \\
\text { schody i nogi). } \\
\text { Postać staruszki } \\
\text { widziana przez prze- } \\
\text { szklone drzwi tarasowe - } \\
\text { efekt zamazanego, nakła- } \\
\text { dającego się obrazu. } \\
\text { Odejście kamery od tej } \\
\text { sytuacji ponad werandę, } \\
\text { dach domu, okolicę (per- } \\
\text { spektywa ptasia). }\end{array}$ & $\begin{array}{l}\text { Odgłosy wprowadzają- } \\
\text { cych się do domu dzieci. } \\
\text { Śmiechy, krzyki, instru- } \\
\text { menty. } \\
\text { Motyw muzyczny: flet, } \\
\text { harfa. } \\
\text { Nawoływania dziecka: } \\
\text { „Pani Anielo, herbata!”. } \\
\text { Dobijanie się do drzwi. } \\
\text { Odgłosy psa leżącego } \\
\text { na kolanach. }\end{array}$ \\
\hline $\begin{array}{l}\text { Wnioski: } \\
\text { Aniela spełniła swoją } \\
\text { misję, przepisała dom } \\
\text { na rzecz Ogniska Dzieci } \\
\text { „Radość”, poczuła się } \\
\text { potrzebna. Bez spe- } \\
\text { cjalnych przygotowań } \\
\text { zasypia, przechodząc } \\
\text { w zaświaty. Odchodzi } \\
\text { razem z „życiem” fili- } \\
\text { żanki, do „świata kubka” } \\
\text { nie pasuje. To śmierć } \\
\text { naturalna, spokojna. }\end{array}$ & $\begin{array}{l}\text { Wnioski: } \\
\text { Filiżanka (kubek her- } \\
\text { baty) podany kobiecie } \\
\text { funkcjonuje jako symbol } \\
\text { spokojnej starości, spo- } \\
\text { koju i harmonii. Zdjęcia } \\
\text { pokazujące śmierć jako } \\
\text { przejście w krainę snu, } \\
\text { marzeń oznaczają odre- } \\
\text { alnienie aktu śmierci. }\end{array}$ & $\begin{array}{l}\text { Wnioski: } \\
\text { Dziewczynka jest świad- } \\
\text { kiem spokojnej śmierci } \\
\text { Anieli, co wprowadza } \\
\text { współegzystencję sta- } \\
\text { rości i młodości. Nowa } \\
\text { droga, wejście w życie } \\
\text { (młodzi podopieczni } \\
\text { ogniska młodzieżo- } \\
\text { wego wprowadzają się } \\
\text { do domu) zestawione } \\
\text { zostaje z łagodnym zej- } \\
\text { ściem ze świata po speł- } \\
\text { nionym życiu (Aniela). }\end{array}$ \\
\hline
\end{tabular}

W różny sposób można zakończyć takie rozważania. Najlepiej zaproponować uczniom redakcję wpisu na czat, który mieli okazję poznać, a tym samym uzyskać ich opinię na temat „Czy zgadzasz się ze stwierdzeniem, że śmierć przestała pasować do współczesnego świata?”.

\section{Motyw starości}

Ten sam film może posłużyć do omówienia i zdefiniowania „starości - pojęcia, które ewoluuje we współczesnym świecie, a które wspiera ciągle ta sama w gimnazjum egzemplifikacja lekturowa - Stary człowiek i morze Ernesta Hemingwaya. Z jednej strony, można stwierdzić, 
że „starość robi dziś furorę, jest wszechobecna” (Bois 1996, 11), z drugiej strony, prezentacja dziarskich przedstawicieli "trzeciego wieku” to przejaw lęku przed przykrą starością, ograniczającą funkcje ciała i umysłu. W podręcznikach gimnazjalnych pojawiają się odniesienia do mądrej, dostojnej starości (Dar Czesława Miłosza, Nic dwa razy Wisławy Szymborskiej), figur chłopskiego losu (fragment Chłopów Władysława Reymonta poświęcony Jagacie) czy też figury babci, która stara się nie przeszkadzać młodym (Koncert życzeń Tadeusza Różewicza, Starość Marii Pawlikowskiej-Jasnorzewskiej). Te utwory tworzą dobry kontekst dla filmowej wersji motywu. Ogromne znaczenie dla przekazu filmu ma wybór aktorki, która zagrała główną rolę. Danuta Szaflarska, której stuletnie życie rozpoczęło się na Sądecczyźnie, przeżyła traumatyczny czas II wojny światowej, obserwowała zmianę ustroju w Polsce, postępującą cyfryzację świata. Trudne doświadczenia nie zgasiły w niej pogody ducha, nie odebrały zadowolenia z życia. Dwa lata temu ci sami twórcy (Kędzierzawska i Reinhart) zrealizowali dokument Inny świat, w którym przez symboliczne 97 minut Szaflarska opowiada o swoim życiu, trudne wspomnienia przełamuje wesołymi anegdotami. W analizowanym obrazie filmowym symboliczna staje się scena, w której bohaterka grana przez Szaflarską kołysze się z dziecięcym szaleństwem na ogrodowej huśtawce.

Aby uchwycić „starość” zobrazowaną w filmie, najlepiej scharakteryzować kontrastowe postaci: babcię Anielę i jej wnuczkę na podstawie języka, którym bohaterki się posługują. Konieczne jest odtworzenie fragmentu filmu oraz udostepnienie uczniom do pracy zapisu sceny „Wnusia”. Pierwsze refleksje powinny zawiązać się wokół pytań: Co przedstawia scena?; Kim są dla siebie bohaterki?; Jakie światy reprezentują?; Jaka formę ma ich dialog? Odpowiadając na pytania, klasa przechodzi przez podstawowe informacje o scenie: przedstawia zwiedzanie starego domu, wietrzenie starych kątów. Właścicielka, pani Aniela, oprowadza swoją ośmioletnią wnuczkę i opowiada o latach świetności domu. W pewnej chwili stajemy się świadkami słownego i poglądowego pojedynku babci i wnuczki, reprezentantek dwóch światów, które nie mogą się zrozumieć. Zgodnie z oczekiwaniami nauczyciela uczniowie mają scharakteryzować pozycje starości i młodości, reprezentowane w filmie przez bohaterki oraz opisać rozkład sił miedzy nimi. Zestawienie słów babci i reakcji wnuczki przynosi owocne wnioski.

\begin{tabular}{|c|c|}
\hline Aniela - babcia & Wnuczka \\
\hline $\begin{array}{l}\text { A żebyś ty zobaczyła, jak tutaj było } \\
\text { pięknie...Chodź, chodź, coś ci pokażę! } \\
\text { (miłość do domu, wspomnienia, ener- } \\
\text { gia, zapał, próba zainteresowania } \\
\text { wnuczki) }\end{array}$ & $\begin{array}{l}\text { Ty masz chyzia na punkcie tego } \\
\text { domu... ( ziewa ) } \\
\text { (lekceważenie, brak zrozumienia dla } \\
\text { przeszłości babci) }\end{array}$ \\
\hline
\end{tabular}




\begin{tabular}{|l|l|}
\hline $\begin{array}{l}\text { Żebyś ty wiedziała, jak tu było pięknie } \\
\text { przed wojną... (powrót do świata } \\
\text { młodości i szczęścia) }\end{array}$ & $\begin{array}{l}\text { O tym, co przed wojną, już tysiąc } \\
\text { razy mówiła.. } \\
\text { (traktowanie babci jak wariatki, } \\
\text { wieczne zmęczenie, znudzenie) }\end{array}$ \\
\hline $\begin{array}{l}\text { A chcesz wziąć na pamiątkę? (poka- } \\
\text { zuje zabawk) (sentymentalizm, } \\
\text { radość z drobiazgu) }\end{array}$ & $\begin{array}{l}\text { Na pamiątkę to mogę wziąć twój pier- } \\
\text { ścionek babunia! (materializm) }\end{array}$ \\
\hline $\begin{array}{l}\text { W ogóle cię nie interesuje to, co ja } \\
\text { mówię... (uświadomienie sobie prze- } \\
\text { paści pokoleniowej, kulturowej) }\end{array}$ & $\begin{array}{l}\text { Yhy... (brak ogłady, chęci } \\
\text { porozumienia) }\end{array}$ \\
\hline $\begin{array}{l}\text { Nie mówi się babcia, tylko babciu, } \\
\text { nie mama, tylko mamo, nie tata, tylko } \\
\text { tato! (kultura języka, zasadniczość, } \\
\text { dyscyplina języka i życia) }\end{array}$ & $\begin{array}{l}\text { No to dasz mi go babcia? Nu... No } \\
\text { dasz mi, proszę babcia, uuu, babcia... } \\
\text { (lekceważenie zasad, bylejakość, } \\
\text { konsumpcja) }\end{array}$ \\
\hline $\begin{array}{l}\text { To już niedługo, moja złota. Musisz się } \\
\text { modlić, żeby babka wyciągnęła nogi } \\
\text { (starość, ironiczne podejście do samej } \\
\text { siebie) }\end{array}$ & $\begin{array}{l}\text { A ja mam 8 lat, a ty jesteś stara! } \\
\text { (młodość, obrona przez atak) }\end{array}$ \\
\hline
\end{tabular}

Wizualizacja materiału analitycznego odsłania, jak zmieniają się role przypisywane bohaterkom. Wprawdzie Aniela, wykluczona przez rodzinę, jest ofiarą społecznego ostracyzmu, jednak sama walczy o swą użyteczność; jest dziarska, pełna zapału i optymizmu, a ośmioletnia wnusia znudzona i zmęczona życiem. Widz nie ma wątpliwości, po której stronie jest wartość dobrego, uczciwego życia. Na przykładzie Anieli obserwuje osobiste doświadczenie starości, „osobiste przeżycie każdego człowieka”, które jest dalekie od schematów kulturowych i społecznych (Bois 1996, 313). Staruszka jest de facto młodsza od swej wnuczki.

\begin{tabular}{|c|c|c|}
\hline BABCIA ANIELA & WNUCZKA \\
\hline $\begin{array}{c}\text { zapał } \\
\text { energia } \\
\text { optymizm } \\
\text { troska o kondycję } \\
\text { dyscyplina } \\
\text { pasja }\end{array}$ & $\begin{array}{c}\text { wmęczenie } \\
\text { znudzenie } \\
\text { zniechęcenie } \\
\text { zaniedbanie } \\
\text { rozpuszczenie } \\
\text { bierność }\end{array}$ \\
\hline
\end{tabular}

Porównanie bohaterek stanie się jeszcze bardziej wyraziste po zastosowaniu piramidy obrazującej ich systemy wartości. 
babcia Aniela

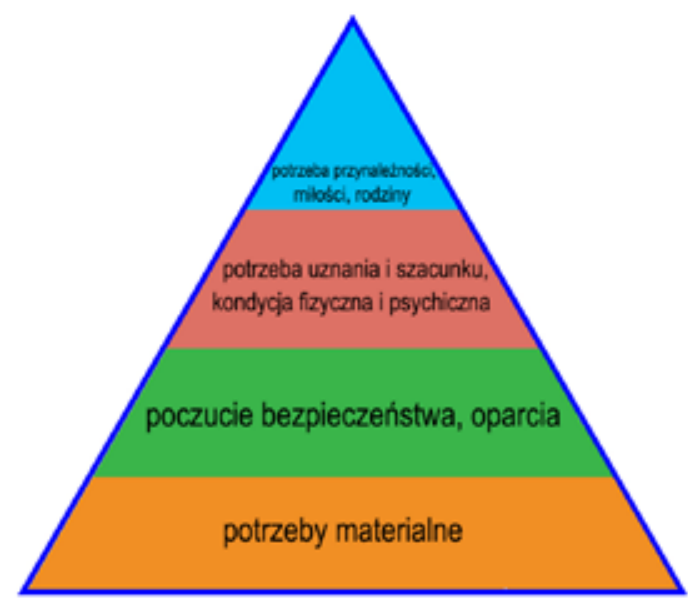

wnuczka

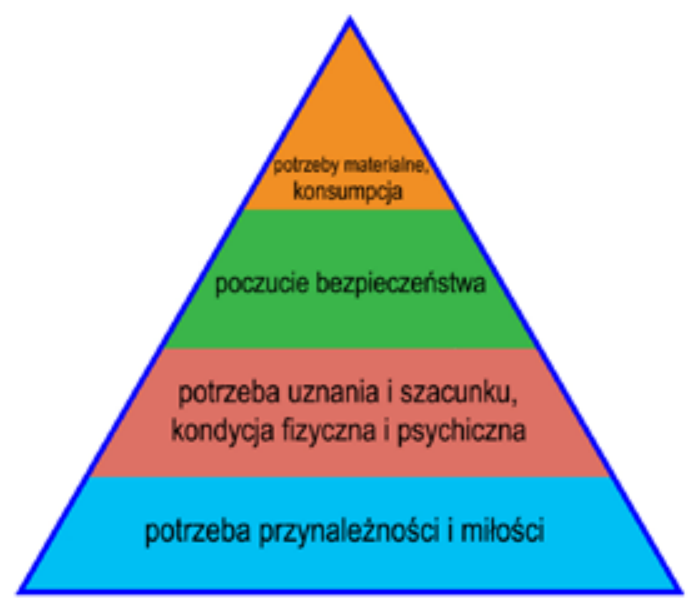

Uczniowie powinni zwerbalizować wnioski z lekcji: starość Anieli, bohaterki filmu, wydaje się bardziej pasować do współczesnego świata przez swoją energię, plany, emocje niż zmanierowana młodość wnuczki. Z drugiej strony, Aniela jest reprezentantką świata odchodzącego, który stawia „być" nad „mieć”. Nadzieją są pokazani w filmie młodzi ludzie z ogniska młodzieżowego, ich amatorska orkiestra jest symbolem marzeń i pasji. Przekazanie domu na rzecz dzieci i ich opiekunów z ogniska młodzieżowego jest aktem niezgody na wykluczenie, próbą zaistnienia we współczesnym świecie. Ten pojedynczy zapis starości Anieli realizuje założenia mitu dionizyjskiego, w którym śmierć jest tak bliska aktowi urodzenia. Bohaterka spokojnie „odchodzi”, by dać początek nowemu życiu w postaci aktywnego, roześmianego, umuzycznionego ogniska młodzieżowego.

Zaplanowana lekcja jest też okazją do ćwiczeń nad poprawnością języka. Jednym z końcowych punktów lekcji może być laboratorium językowe - wypisanie przykładów językowych, jakie Aniela wymienia, poprawiając swoją wnuczkę. Jeżeli klasa określi formy gramatyczne wymienionych wyrazów oraz opisze to zjawisko językowe, uda się zrealizować jeszcze jeden cel wspólnych zajęć.

\section{Refleksja na podłożu filmowym}

W podręczniku gimnazjalnym Swoimi słowami (Podręcznik do kształcenia literackiego i kulturowego, klasa II) znaleźć można plan lekcji poświęconej rytuałowi umierania i pytaniom o współczesne traktowanie „odejścia” bliskich, który oparty jest na fragmencie Chłopów i obrazie Aleksandra Gierymskiego Trumna chłopska. Czy musimy na tym poprzestać? Odpowiadając na wątpliwości Joanny Hobot związane z zapisami doświadczeń starości (Hobot 2010), jestem zdania, że nauczyciele poloniści ciągle wierzą w możliwość wartościowego, ale i atrakcyjnego dla młodych ludzi pokazania tego typu doświadczeń... Może tych niewierzących przekona propozycja metodyczna związana z filmem Pora umierać? Sądzę, 
że choć współczesny człowiek unika w realnym życiu bezpośredniego kontaktu ze śmiercią, to nie oznacza, że nie ulega on jednocześnie fascynacji ars moriendi i nie poszukuje jej sensu w sztuce. Podobnie starość okazuje się pojęciem ciekawym, ciągle w nowy sposób formułowanym i rozumianym przez pryzmat indywidualnych doświadczeń. Te tematy potrzebują odpowiedniego przekaźnika; wydaje się, że film jest w tym momencie najlepszym wyborem. Uczeń - odbiorca filmu, analizując i interpretując to dzieło, „pielęgnuje $\mathrm{w}$ sobie rozumienie, doznanie emocji, identyfikację $\mathrm{z}$ bohaterami, w końcu przyjemność" (Bobiński 2011, 230-231). Nauczyciel, kształtując wrażliwość ucznia na tworzywo filmowe, zyskuje pewność, że w ten sposób wzbogaca jego refleksję kulturową oraz rozumienie współczesnych problemów aksjologicznych.

\section{Bibliografia:}

Bobiński Witold, 2010, W poszukiwaniu „czegoś więcej”. O szkolnych próbach kształtowania wrażliwości na dobre filmy, w: Janus-Sitarz A. (red.), Edukacja polonistyczna wobec trudnej rzeczywistości, Kraków.

Bobiński Witold, 2011, Teksty w lustrze ekranu. Okołofilmowa strategia kształcenia literacko-kulturowego, Kraków.

Bois Jean Pierre,1996, Historia starości. Od Montaigne'a do pierwszych emerytur, Marczewska K. (przeł.), Warszawa.

Hendrykowska Małgorzata, 1992, Scenografia jako element dzieła filmowego, w: Trzynadlowski J. (red.), W kręgu filmu, telewizji i teatru, 1992.

Hobot Joanna, 2010, Poetyckie zapisy doświadczenia starości wobec wyzwań świata ponowoczesnego i polonistycznej edukacji, w: Janus-Sitarz A. (red.), Edukacja polonistyczna wobec trudnej współczesności, Kraków.

Kolbuszewski Jacek, 2007, Rozmowa z Mariuszem Urbankiem, "Gazeta Wyborcza" 1.11.2007, adres: http://wroclaw.wyborcza.pl/ wroclaw/1,35769,4632761.html (dostęp: 13.10.2010).

Kowalski Piotr, 2007, Kultura magiczna. Omen, przesą, znaczenie, Warszawa.

Krakowiak Piotr, 2010, Czat z krajowym duszpasterzem hospicjów, http://hospicja.pl/serwis_prasowy/article/122.html (dostęp: 13.10.2010).

Nowakowski Jacek, 2009, Współczesny film dla młodego widza wobec kulturowych i obyczajowych tabu, w: Leszczyński G. (red.), Sztuka dla dziecka jako forma komunikacji społecznej, t. 1, Poznań.

Pora umierać 2007, reż. D. Kędzierzawska, Tandem Taren-To, Kid Film, TP S.A..

Shakespeare Wiliam, 1964, Sonet 73, Sito J. S. (przeł.), http://www.e-teatr.pl/pl/ programy/2014_02/62626/sonety teatr_klasyczny_warszawa_1964.pdf

(dostęp: 15.10.2015). 


\section{O Autorce:}

Małgorzata Masłowska-Taffel - nauczycielka dyplomowana Zespołu Szkół z Oddziałami Sportowymi nr 1 w Poznaniu, absolwentka WFPiK UAM (1996), autorka artykułów metodycznych publikowanych na łamach „Polonistyki”, takichjak: Bohaterowie Haruki Murakamiego na lekcjach polonistycznych (2012), Uczta Babette - uczta dla duszy i ciała. Wielozmysłowe odczytanie opowiadania i filmu na lekcjach języka polskiego dla uczniów szkoły ponadpodstawowej (2013), Fotografia prasowa jako sposób uchwycenia i wywoływania ludzkich emocji (2014) 